\title{
Mechanisms and substances involved in clastic activity of root resorptions -
}

\section{literature review}

Mecanismos e substâncias envolvidas na atividade clástica das reabsorções radiculares - revisão de

\author{
literatura
}

Mecanismos y sustancias que participan en la actividad clásica de las resorciones de raíces revisión de la literatura

Received: 09/24/2021 | Reviewed: 09/29/2021 | Accept: 12/28/2021| Published: 01/01/2022

Luciano Barreto Silva

ORCID: https://orcid.org/0000-0002-1508-4812

Faculdade de Odontologia do Recife, Brazil E-mail: lucianobarreto63@gmail.com

Guilherme Marinho Sampio

ORCID: https://orcid.org/0000-0003-4441-7601 Faculdade de Odontologia do Recife, Brazil

E-mail: guilhermemarinhosampaio@gmail.com

Rodolfo Scavuzzi Carneiro Cunha

ORCID: https://orcid.org/0000-0001-7110-848X

Faculdade de Odontologia do Recife, Brazil

E-mail: scavuzzi@gmail.com

Felipe Leonardo de Melo Almeida Fonseca

ORCID: https://orcid.org/0000-0001-7967-0215

Faculdade de Odontologia do Recife, Brazil

E-mail: felipeleonardodemelo@gmail.com

Paulo Melo Júnior

ORCID: https://orcid.org/0000-0001-9926-5348

Faculdade de Odontologia do Recife, Brazil

E-mail: paulo.reis@upe.br

Sandra Sayão Maia

ORCID: https://orcid.org/0000-0001-6808-9775 Faculdade de Odontologia do Recife, Brazil

E-mail: sandrinhasayao@hotmail.com

Alexandrino Pereira dos Santos Neto

ORCID: https://orcid.org/0000-0001-8250-5763 Faculdade de Odontologia do Recife, Brazil E-mail: alexandrinoneto@live.com

Ailton Coelho de Ataíde Filho

ORCID: https://orcid.org/0000-0002-8105-4259

Faculdade de Odontologia do Recife, Brazil E-mail: ailtonataide@hotmail.com

\begin{abstract}
Aim: to research through literature review, the mechanisms involved in the establishment of root resorptions. Mediators such as interleukins, prostaglandins, nitric oxide and systemic calcium available were studied in this review. Methods: On line searches were accomplished by scrutinizing the database available from PUBMED Central, BVS/BIREME. Web of Science, Science Direct, Periodic Portal from CAPES, as well as The Cochrane Library and PROSPERO were also used. The inclusion criteria were articles that described osteoclastic activity involving the hard dental tissues (cement, dentin and enamel). The search acquired 35 articles and excluded other 30. The articles acquired ranged from 1976 up to 2017. Results: the results showed that the combination of the immunologic mediators researched above will be the determinant factors on the establishment of root resorptions. Conclusions: Prostaglandins, Interleukins as well as the systemic calcium available are some of the most important factors for the establishment of root resorptions. Their final outcome, however, depends directly on the quality of injury inflicted over the group of teeth, or single tooth, involved.
\end{abstract}

Keywords: Allergy and immunology; Tooth resorption; Root resorption; Cytokine-Induced Killer Cells. 


\section{Resumo}

Objetivo: pesquisar, por meio de revisão da literatura, os mecanismos envolvidos no estabelecimento das reabsorções radiculares. Mediadores como interleucinas, prostaglandinas, óxido nítrico e cálcio sistêmico disponíveis foram estudados nesta revisão. Métodos: Foram realizadas buscas on-line nas bases de dados PUBMED Central, BVS / BIREME, Web of Science, Science Direct, Portal de Periódicos da CAPES, bem como The Cochrane Library e PROSPERO.O critério de inclusão foram artigos descrevendo atividade de osteoclástica envolvendo tecidos dentais (tecido, dental,esmalte). A pesquisa abordou 35 artigos e excluiu 30 artigos. Os artigos selecionados foram dos anos de 1976 até 2017.Resultados: os resultados mostraram que a combinação dos mediadores imunológicos acima pesquisados serão os fatores determinantes no estabelecimento de reabsorções radiculares. Conclusões: Prostaglandinas, interleucinas e também o cálcio sistêmico disponível são alguns dos fatores mais importantes para o estabelecimento de reabsorções radiculares. Seu resultado final, entretanto, depende diretamente da qualidade da injúria infligida ao grupo de dentes, ou dente único, envolvido.

Palavras-chave: Alergia e imunologia; Reabsorção dentária; Reabsorção de raiz; Células Matadoras Induzidas por Citocinas.

\section{Resumen}

Objetivo: investigar, a través de una revisión de la literatura, los mecanismos involucrados en el establecimiento de reabsorciones radiculares. En esta revisión se estudiaron mediadores como las interleucinas, las prostaglandinas, el óxido nítrico disponible y el calcio sistémico. Métodos: Las búsquedas en línea se realizaron examinando la base de datos disponible en PUBMED Central, BVS / BIREME. También se utilizaron Web of Science, Science Direct, Portal Periódico de CAPES, así como The Cochrane Library y PROSPERO. Los criterios de inclusión fueron artículos que describieran la actividad osteoclástica que involucraba los tejidos dentales duros (cemento, dentina y esmalte). La búsqueda adquirió 35 artículos y excluyó otros 30. Los artículos adquiridos variaron desde 1976 hasta 2017. Resultados: los resultados mostraron que la combinación de mediadores inmunológicos investigados anteriormente serán los factores determinantes en el establecimiento de reabsorciones radiculares. Conclusiones: Las prostaglandinas, las interleucinas y también el calcio sistémico disponible son algunos de los factores más importantes para el establecimiento de resorciones radiculares. Su resultado final, sin embargo, depende directamente de la calidad de la lesión infligida en el grupo de dientes, o diente único, involucrado.

Palabras clave: Alergia e inmunología; Reabsorción dental; Reabsorción de raíces; Células Asesinas Inducidas por Citosinas.

\section{Introduction}

Much has been written about root resorptions and their relationship with the clasts, main responsible cell types for the resorptive events that take place for dental roots to be destroyed. Not only until ten years ago had the immunological aspects and mechanisms of this pathology been initially described, opening a new era for researchers (Santos, 2007).

Pathological root resorptions can be described as the resorptive process of the hard dental and osseous tissues due to some sort of injury applied straight over the teeth, or more specifically over one group of them. The hard tissues involved are the alveolar bone, cement and dentin, not affecting the enamel. In normal conditions and due to the very nature of the developmental process of the dental germs, which have to be hidden and protected against the cells and substances produced by the immunological system, the roots are protected by cementum, while dentin is protected by the enamel (Sandy, 1993). Recently in the scientific literature, there have been evidence concerning the role of the immunological system in the onset and development of root resorptions, independently of the type they may be categorized (Alam \& Gorska, 2003).

From this point of view, it is necessary that trauma be applied over the teeth for the immune cells to interpret dentin as a non self structure, unleashing specific cell types called clasts over dentin, from the external part of the roots (external root resorptions) or from inside out (internal root resorptions) (Chaplin, 2003).Regardless of their nature, chemotactic substances have to be produced so that the immune system is informed that some sort of aggression is being inflicted in a specific part of the organism. Such communication is accomplished with the aid of peptides named cytokines, more specifically the interleukins (IL), and more recently, there have been evidence of the role of prostaglandins (PG) in the process.

The aim of this article is to describe the role of the cytokines involved in the process, as well as the role of PG in the onset and development of root resorptions. 


\section{Literature Review}

One way or another, pathological root resorptions are somehow related with some sort of injury is applied over the teeth, singularly or in groups. If the stimuli are strong enough, temporary or permanent damage will appear, which will be the determinant factor for the establishment and development of the different sorts of root resorptions. Anyway, the inflammatory response of the organism is the main, if not the most important factor for the onset of root resorptions, more specifically the exudate produced due to the vascular changes thereafter (Félix, 1976). In the consequent inflammatory exudate, there is a great amount of leukocytes, plasmatic and tissue proteins, local traditional and stem cells, and many times there is also the presence of the aggressor agent itself, especially when it is of biological origin, such as bacteria, in the site of injury; as well as other substances usually forgotten by the majority of the articles that describers the pathology of these dental resorptions (Limeback, 1991).

After trauma, especially those mechanical ones when the tooth involved is explanted from the alveolar bone, and reinserted afterwards, there is a group of factors involved that may be determinant for what will happen to the surrounding teeth and the tooth directly involved (Pohl, 2005). Mechanical impacts, foreign bodies, microorganisms and time lapse for dental assistance, as well as the way the teeth are transported to the dental offices will be variants which, in more or less importance, will determine the extent of the damage and the prognosis of the case in debate. When all these protagonists are present in the same site, reciprocal interactions take place in an attempt to reestablish homeostasis (Shioi, 1994). Among the products produced in this process, there is the increased production of cytokines, especially IL- $1 \alpha$ and $\beta$, IL-2 and IL-6, as well as TNF- $\alpha$; Epidermal Growth Factor (EGF), and the indirect increase of lipopolysaccharides (LPS) or endotoxins for inducing intense cellular stress with liberation of great amounts of local mediators (Arsenault, 1999).

Nitric Oxide (NO) is one of these mediators. It is regarded as a signaling molecule liberated by injuries that plays a significant role in the modulation of inflammation. In normal physiological conditions, it offers anti-inflammatory effects within the tissues. However; it may be considered a pro-inflammatory mediator, since it is an effector molecule of cellular injury (Banick, 1997). It is able to modulate the release of various inflammatory mediators from a wide range of cells participating in inflammatory responses (e.g., leukocytes, macrophages, mast cells, and platelets) (Beckman, 1996). NO also seems to play a significant role in controlling blood flow, leukocyte adhesion the vascular endothelium promoting diapedeses, as well as regulating the activity of numerous enzymes powerful enough to have a pertinent impact on the effective inflammatory response (Clancy, 1992).

Nitric oxide is liberated in gas form, unleashed by the cellular stress which finally leads to the formation of the arachidonic acid, important for the synthesis of prostaglandins and leukotrienes (Davies, 1997). In addition to modulating prostaglandin stimulation in the cellular signaling as a lipid second messenger able to regulating signaling enzymes, like PLC$\delta$, and $\underline{\mathrm{PKC}}-\alpha$, and $-\beta$, arachidonic acid also acts as a vasodilator, increasing blood flow and the consequent pro-inflammatory effects (Baynes, 2005).

It all begins with a trauma inflicted over the teeth, NO liberated seems to intensify the inflammatory cardinal signs, becoming a pro-inflammatory mediator. As the injury is evolves, fibroblasts present in the periodontal ligament (PDL) will begin their way to the healing process, while the neurovascular elements inside the root canal, in the majority of the times, will undergo permanent damage. However; the extent of the damage in the dental pulp will depend also on the width of the apex foramen, and sometimes if there is horizontal or vertical fractures in the roots. This healing process will also be affected by the liberation of Prostaglandins and the serum calcium available.

Prostaglandins (PGs) are designated as a group of physiologically active lipid compounds denominated eicosanoids, with many hormone-like effects in animals. They were first isolated from the seminal liquid from the prostate, and therefore 
were denominated with the suffix "glandins" associated with this gland. PGs are derived from arachidonic acid, and undergo cyclization under the action of cyclooxygenase enzyme (COX) to form a pentane ring, receiving various unsaturations.

Bone metabolism is partially regulated by PGs (Saito, 1991), particularly by PGE2, which promotes morphologic changes in the clasts and blasts by increasing the intracellular levels of CAMP (cyclic adenosine monophosphate) (Shanfeld, 1986; Kalaizic, 2014). Interestingly, PGE2 seems to increase mRNA (messenger RNA) synthesis, along with protein secretion of the Receptor Activator of Nuclear factor kappa- $\beta$ Ligand (RANKL) (Mayahara, 2012): the basis of bone modulation. Nevertheless, there was still an increase amount of root resorptions associated with concentrations of PGE2 injections (Cağlaroğlu, 2012; Yamasaki, 1980). Inevitably, they act like local vasodilators, also inhibiting blood platelet aggregation, allowing even more blood influx in the affected area. One of their main features is to be synthesized within the walls of the blood vessels preventing unnecessary clot formation, in addition to regulating smooth muscle tissue contraction (KURZROCK, 1930).

$P G s$ were Initially thought to be unleashed from the cells via passive diffusion, mainly because of their being high lipophilic, and therefore at least theoretically would penetrate the cell membrane by this via. Nevertheless, the discovery of the existence of a transporter for them (PGT, SLCO2A1), which seemed to mediate their uptake in the cells, soon demonstrated that diffusion itself could not explain their passage the cellular membrane into the cytoplasm. Their release has recently also been demonstrated to be mediated by a specific transporter: the multidrug resistance protein 4 (MRP4, ABCC4), one of the members of the vast family of ATP-binding cassette transporter. It is still cloudy if MRP4 is the only transporter releasing prostaglandins involved in the process, but its role seems to be fundamental for their entrance in the cells (Moreno, 2017). Root resorptions followed by impact trauma seems to undergo the effects of vasodilatation caused by Prostaglandin interplay.

The complexity of the way in which root resorption may be established also requires the interplay of systemic calcium available (Kehoe,1996). Although it may seem obvious that the amount of this ion available in the organism will be determinant for the resolutions of any hard tissue pathology, it is sometimes neglected and many times not requested in traditional blood examinations concerning this pathology. It is a fact that low levels of calcium may stimulate the emergence of many diseases, such as secondary hypoparathyroidism; as well as an increase in the secretion of parathyroid hormone (PTH) and vitamin D metabolites. The effect of PTH on the periodontal ligament seems to be pertinent, since PDL tissues are involved in the formation of the clastic cells that will unleash root resorption formation (Shiraishi, 2001). PTH has been demonstrated as able to rise the number of osteoclasts, as well as their progenitor cells, following its interference (Soma, 1999). It seems that clast-like cells may cause root and bone resorption even under normal treatment conditions (Reitan and Rygh, 1994).

The immune system can be shortly described a complex organ whose aim is to make human existence possible by allowing appropriate self-defense against injuring microbial lives and non-self structures (Basedovsky, 1996). Sometimes however, it may interpret self-structures as foreign bodies, destroying them and establishing what researchers call auto-immune diseases. This is exactly what happens in pathological root resorptions, where dentin is hidden from the immune system for being antigenic and therefore able to induce immune responses if exposed. Once an injuring factor is strong enough to damage the radicular cementum that covers the roots of the teeth, then an immune response will take place, being reversible or irreversible (Bishop, 1992). It is partially obtained by the synchronized synthesis of the small cytokines named chemokines (CKs) and their interaction on their counterparts, the chemokine receptors (CKRs) located on the surfaces of many immune-competent cells. In this sense CKRs define the subpopulation sort of cells that will be recruited in each phase of the immunological response. The term chemokines comes from "chemoattractant cytokines", able to induce faster and more efficient directed chemotaxis in nearby responsive cells. The family of the cytokines is vast, and includes the Interleukins (ILs) and Chemokines (CKs), Interferon (IFN), Growth Factor (GF), Tumor Necrosis Factor (TNF) and Coloning-stimulating Factor (CSF) (ABBAS, 1996). Tumor Necrosis Factor alpha (TNF- $\alpha$ ) has also been related to increase root resorptions after trauma (Boyce, 2005). 
The main proteins involved in inflammatory processes in mammals are undoubtfully the cytokines. They play fundamental roles in virtually all of the aspects concerning inflammation modulated by immunity, which have direct influence on the recruitment, proliferation and arrival to the inflamed tissue. From the large family of the cytokines, interleukins have been related to hard tissue resorptions since 1979 in the first reports of inflammatory researches, described as secreted polypeptides liberated by leucocytes to attract other similar lymphoid cells to the site of tissue aggressions (Borish, 2003). They are a vast group of immunomodulatory proteins which generate a wide range of different and sometimes contradictory responses, depending on their type and surface cell receptor in which they bind, specifically depending on the ligands involved (Brocker, 2010). Following this point of view, Interleukins can exert antagonist inflammatory and anti- inflammatory functions, and few of them may work as chemoattractants for helper T cells, resembling the actions of chemokines. ILs are regarded as pertinent mediators for the physiological response to infection, also contributing significantly to the pathophysiology of a wide sort of illness, modulating growth, differentiation, proliferation and also activation during an immune response (Commins, 2010). Up to the construction of this article, 35 interleukins have been identified; some of them are pro-inflammatory, such as IL-1 $\alpha$ and IL-1 $\beta$, which act on macrophages, thymocytes, CNS, and others. These interleukins promote the activation, costimulation and also the secretion of other acute-phase proteins, such as C-Reactive Protein, increasing inflammatory bone and hard-mineralized dental structures, while promote Th17 response (Fearon, 1996).

On the other hand, IL-10 has anti-inflammatory actions, and is able to diminish the intensity of the inflammatory signs; it is responsible for immune suppression by decreasing antigen presentation and MHC class II expressions of APC cells, particularly dendritic cells, down-regulating pathogenic Th1, Th2 and Th17 responses (Haddad, 2002).

\section{Methodology}

For the accomplishment of this work, on line searches were carried out by searching the database available from BVS/BIREME and PUBMED Central. Other portals such as Web of Science, Science Direct, Periodic Portal from CAPES, as well as The Cochrane Library and PROSPERO were also used. The articles focused on the substances and cells responsible for the onset and development of root resorptions.

\section{Results and Discussion}

The complexity of the processes necessary for the establishment of root resorptions requires attention and care for the understanding of how to ovoid them and, when it is too late and the pathology has already been installed, how to treat them properly. One way or another, a sort of trauma is necessary to unleash the gases, substances as well as the ions necessary for the activation of the immune system to recruit, proliferate and attract the competent cells to the site of the aggression.

If an impact trauma is potent enough to cause root damages, a number of variables will act to determine what will happen to the tooth in question. The first possibility is the existence of foreign bodies, such as sand, grass or any other environmental element present in the surroundings of where the injury took place. From this point, the rupture of the periodontal ligament as well as dental or bone structure breakdown, such as the root itself, alveolar bone or the dental crown will be pertinent situations to be analyzed. Traditional approaches for the clinical treatment of root resorptions usually target on interleukins as the main responsible for the initiation of the pathological process. In spite of all their importance in the modulation and regulation of the process, other proinflammatory substances also play significant roles by intensifying the vascular alterations in the site of traumas. Nitric oxide and PGs, for instance, are almost never cited in the start up of the process.

Traumas applied over a group of teeth cause the liberation mediators that are unleashed immediately, and others that will be progressively liberated throughout the evolution of the process. NO is immediately produced after the physical stress 
produced, initiating the vascular alterations necessary for the beginning of the healing process which may lead to surface root resorption, or reversible inflammatory root resorptions with a better prognosis. The damages caused in the PDL, many time with ruptures in the ligament, will liberate Prostaglandins, which will influence macrophage secretory activity in order to modulate complement production. The arrival of these Antigen Presenting Cells (APCs) stimulate Interleukin production, more specifically IL-1 $\alpha$, which is produced by these activated cells. IL-1 $\alpha$ develops physiologic, hematopoietic and metabolic activities potent enough to regulate immune responses, by binding to interleukin-1 receptor (Bankers-Fulbright, 1996; Dinarello, 1997). The resultant bone resorptive effect will locally stimulate clastic activity and external root resorption. If the stimulus is strong enough to produce $T N F-\alpha$, the resorptive effects will be amplified.

Whether external root resorption will be continued or halted will depend, among other things, on the amount of dentin exposed after trauma. The antigens present in the dentin proteins will establish immunologic interaction and complementation in order to destroy the mineralized hard tissues. The more amount of systemic calcium available, the better for the healing process.

\section{Conclusion}

Root resorptions have been a challenge for odontology due to complexity and immunological interactions that the process unchain. The great majority of the works approach the role of traditional cells in the development of the resorptions, such as macrophages, odontoclasts and osteoclasts. The role of prostaglandins and nitric oxide (NO) have virtually been forgotten.

This work concludes that, regardless of their classification or origins, root resorptions will be determined by dental traumas and immunologic mediators. In this sense, NO, Prostaglandins, Interleukins and the systemic calcium available seem to be the most important factors for the establishment of root resorptions. The final outcome of the injury inflicted will be the most important factor as for what sort of resorption will be installed as well as its prognostic.

\section{References}

Arsenault, A. L., \& Robinson, B. W. (1999) The dento-enamel junction: a structural and microanalytical study of early mineralization. Calcif Tissue Int. 111.

Banick, P. D., Chen, Q. P., Xu, Y. A., \& Thom, S. R. (1997). Nitric oxide inhibits neutrophil b2 integrin function by inhibiting membrane-associated cyclic GMP synthesis. J Cell Physiol 172: 12-24.

Bankers-Fulbright, J. L., Kalli, K. R., \& McKean, D. J. (1996). "Interleukin-1 signal transduction". Life Sciences. 59 (2): 61-83. 10.1016/0024-3205(96)00135X. PMID 8699924

Basedovsky, H.; Del Rey, A.; Sorkin \& E. et al. (1986) Immunoregulatory feedback between interleukin-1 and glucocorticoid hormones. Science 233, 652-654.

Baynes, J. W.; Marek, H., \& Dominiczak (2005). Medical Biochemistry 2nd. Edition. Elsevier Mosby. 555.

Beckman J, Koppenol W (1996). Nitric oxide, superoxide, and peroxynitrite: the good, the bad, and the ugly. Am J Physiol 271: C1424-C1437.

Bishop, M. A. (1992.) Extracellular fluid movement in the pulp; the pulp/dentin permeability barrier. Proc Finn Dent Soc 88, $331-335$.

Borish, L. C., \& Streinke, J. W. (2003) Cytokines and chemokines. Allergy and Clinc. Immunol., 111, 2.

Boyce, B. F., Li, P., Yao, Z. et al. (2005) TNF-alpha and pathologic bone resorption. Keio J Med 54, 127-131.

Brocker, C., et al. (2010). Evolutionary divergence and functions of the human interleukin (IL) gene family. Human Genomics 5 (1): $30-55$.

Cağlaroğlu, M., \& Erdem, A. (2012) Histopathologic investigation of the effects of prostaglandin E2 administered by different methods on toothmovement and bone metabolism. Korean J Orthod. 42: 118-128.

Chaplin, D. D. (2003) Overview of the immunologic response. Allergy and Clinic. Immunol., 111(2).

Clancy, R., Leszczynska-Piziak, J., \& Abramson, S. (1992). Nitric oxide, and endothelial cell relaxation factor, inhibits neutrophil superoxide anion production via a direct action on the NADPH oxidase. J Clin Invest 90: 1116-1121. 
Davies, N. M., Roseth, A. G., Appleyard, C. B., McKnight, W., Del Soldato, P., Calignano, A., Cirino, G., Wallace, J. L. (1997). NO-naproxen vs naproxen: ulcerogenic, analgesic and anti-inflammatory effects. Aliment Pharmacol Ther 11: 69-79.

Dinarello, C. A. (1997). "Induction of interleukin-1 and interleukin-1 receptor antagonist". Seminars in Oncology. 24(3): S9-81-S9-93.

Fearon, D. T., \& Locksley, R. M. (1996) The instructive role of innate immunity in the acquired immune response. Science $272,50-53$.

Felix R, \& Fleisch H. (1976) The role of matrix vesicles in nucleation. Fed Proc; 35, 169.

Haddad, J. J., Saade, N. E., \& Safieh-Garabedian, (2002) B. Cytokines and neuro-immune-endocrine interactions: a role for the hypothalamic-pituitary-adrenal revolving axis. J Neuroimmunol 133, 1-19.

Kalajzic, Z., Peluso, E. B., Utreja, A., Dyment, N., Nihara, J., Xu, M., et al. (2014) Effect of cyclical forces on the periodontal ligament and alveolar bone remodeling during orthodontic toothmovement. Angle Orthod; 84: 297-303.

Kehoe, M. J., Cohen, S. M., Zarrinnia, K., \& Cowan, A. (1996) The effect of acetaminophen, ibuprofen, and misoprostol on prostaglandin E2 synthesis and the degree and rate of orthodontic tooth movement. Angle Orthod; 66: 339-349.

Kurzrock, R.; \& Lieb, C. C. (1930). "Biochemical Studies of Human Semen. II. The Action of Semen on the Human Uterus". Proceedings of the Society for Experimental Biology and Medicine. 28 (3): 268. doi:10.3181/00379727-28-5265.

Limeback, H. (1996) Molecular mechanisms in dental hards tissue mineralization. Curr Opin Dent.;1:826.

Mayahara K, Yamaguchi A, Takenouchi H, Kariya T, Taguchi H, \& Shimizu N. (2012) Osteoblasts stimulate osteoclastogenesis via RANKL expression more strongly than periodontal ligament cells do in response to PGE(2). Arch Oral Biol ; 57: 1377-1384.

Moreno, J. J. (2017). "Eicosanoid receptors: Targets for the treatment of disrupted intestinal epithelial homeostasis". European Journal of Pharmacology. 796: $7-19$.

Pohl Y, Filippi A, \& Kirschner H. (2005) Results after replantation of avulsed permanent teeth: Endodontic considerations. Dent Traumatol.; 21 : 80-92.

Reitan K, \& Rygh P (1994) Biomechanical principles and reactions. In: Graber T M, Vanarsdall R L (eds) Orthodontics: Current principles and techniques. Mosby, Philadelphia, 96-192.

Saito M, Saito S, Ngan P. W, Shanfeld J, \& Davidovitch Z. (1991) Interleukin 1 beta and prostaglandin E are involved in the response of periodontal cells to mechanical stress in vivo and in vitro. Am J Orthod Dentofacial Orthop; 99: 226-240.

Sandy J. R, Farndale R W, Meikle M. C. (1993) Recent advances in understanding mechanically induced bone remodeling and their relevance to orthodontic therapy d practice. Am. J. Orthod. Dentofacial Orthop., 103(3), 212-222.

Santos, S. H., \& Morosolli A. R. C. (2007). Considerations about external root resorption. SOTAUR Virtual Odontol. 1:2-7.

Shanfeld, J, Jones, J, Laster L, \& Davidovitch Z. (1986) Biochemical aspects of orthodontic tooth movement I. Cyclic nucleotide and prostaglandin concentrations in tissues surrounding orthodontically treated teeth in vivo. Am J Orthod and Dentofac Orthop; 90: 139-148.

Shioi A, Ross F. P, \& Teitelbaum S. L. (1994) Enrichment of generated murine osteoclasts. Calcif. Tissue Int., 55(5), $387-394$.

Shiraishi C, Hara Y, Abe Y, Ukai T, \& Kato I (2001) A histopathological study of the role of periodontal ligament tissue in root resorption in the rat. Archives of Oral Biology 46: 99-107.

Soma S, Iwamoto M, Higuchi Y, \& Kurisu K (1999) Effects of continuous infusion of PTH on experimental tooth movement in rats. Journal of Bone and Mineral Research 14: 546-554;

Yamasaki K, Miura F, \& Suda T. (1980) Prostaglandin as a mediator of bone resorption induced by experimental tooth movement in rats. J Dent Res; 59: 16351642 